\title{
$\begin{array}{lllllllllllllllllllll}\mathbf{R} & \mathbf{E} & \mathbf{C} & \mathbf{E} & \mathbf{N} & \mathbf{Z} & \mathbf{J} & \mathbf{E} & \mathbf{I} & \mathbf{S} & \mathbf{P} & \mathbf{R} & \mathbf{A} & \mathbf{W} & \mathbf{O} & \mathbf{Z} & \mathbf{D} & \mathbf{A} & \mathbf{N} & \mathbf{I} & \mathbf{A}\end{array}$
}

ROCZNIKI HUMANISTYCZNE

Tom LXVII, zeszyt 7 - 2019

\section{W POSZUKIWANIU ŹRÓDEE BIAŁORUSKIEJ TOŻSAMOŚCI NARODOWEJ}

\author{
АНЖЭЛА М. МЕЛЬНІКАВА, Наџьыянальна-светапоглядныя каардынаты \\ беларускай літаратуры першай трэизі XX стагоддзя, Гомель: ГДУ \\ імя Ф. Скарыны, 2016, 214 с.
}

DOI: http://dx.doi.org/10.18290/rh2019.67.7-16

Wydana w 2016 roku nakładem wydawnictwa Homelskiego Uniwersytetu Państwowego monografia Andżeli Mielnikawej wpisuje się w nurt badań komparatystycznych, sytuujących się na pograniczu literaturoznawstwa, socjologii i historiozofii. W centrum zainteresowania Badaczki znajduje się białoruska literatura pierwszego trzydziestolecia XX wieku, analizowana w kontekście uobecniających się $\mathrm{w}$ niej zagadnień tożsamościowych, mentalnościowych, historiozoficznych ${ }^{1}$.

Okres ten to w literaturze i kulturze białoruskiej czas intensywnych poszukiwań twórczych, znaczących osiągnięć artystycznych, sygnowanych nazwiskami wybitnych krytyków literackich, pisarzy i poetów, m.in.: Wacława Łastouskiego, Maksima Bahdanowicza, Zmitroka Biaduli, Maksima Hareckiego, Michasia Zareckiego, Uładzimira Żyłki czy Kuźmy Czornego. Poprzez zwrot do ich twórczości i myśli krytycznej Autorka próbuje zrekonstruować proces kształtowania się myśli narodowej (w szerokim jej rozumieniu): „.. сёння перад айчынным літаратуразнаўствам стаіць задача больш поўнага, канцэптуальнага даследавання як маральна-філасофскага, этычнага аспекту мастацкіх твораў, так і нацыянальна-светапоглядных каардынат прыгожага пісьменства" (s. 7).

\footnotetext{
${ }^{1}$ Warto podkreślić, że ważnym punktem odniesienia dla A. Mielnikawej jest monografia Stefanii Andrusiw, przybliżająca podobne zagadnienia na materiale literatury ukraińskiej. Zob. С. Андрусів, Модус начіональної ідентичності: Львівский текст 30-х років XX cm., Тернопіль: Львівский національний університет імені Ивана Франка, 2000.
} 
Recenzowana monografia składa się z wprowadzenia, sześciu rozdziałów, zakończenia oraz bibliografii. Taka struktura pracy pozwala na szeroką i kompleksową egzemplifikację tytułowego zagadnienia oraz zachowanie przejrzystości dyskursu oscylującego wokół konkretnego, zarysowanego w tytule każdego rozdziału, problemu badawczego.

Rozdział I - Teoretyczne aspekty probleти (Тэарэтычныя аспекты праблеMbl) - stanowi metodologiczną podbudowę dla analiz podjętych w kolejnych rozdziałach monografii. Odwołując się do prac poświęconych problematyce tożsamości narodowej, narodowej samoidentyfikacji, Autorka szczegółowo nakreśla złożoność i wielopłaszczyznowość tych zagadnień, a także ukazuje odmienne stanowiska badawcze, prezentujące te kwestie (W. Pazniakou, A. Ancipienka, K. Michalski, W. Bułhakau). Największy użytek dla powziętej koncepcji widzi w pracach teoretycznych Rolanda Barthesa ${ }^{2}$, do których będzie odwoływać się w swoich analizach. Autorkę interesuje także to, w jaki sposób, za pomocą jakich narzędzi i zabiegów artystycznych problematyka narodowa uobecnia się w wybranych utworach literatury białoruskiej. Poprzez analizę tekstów krytycznych W. Łastouskiego, M. Bahdanowicza, M. Hareckiego, A. Łuckiewicza, A. Adamowicza, S. Pałujana, A. Babareki, F. Kuncewicza i in. Mielnikawa dowodzi, że białoruskie literaturoznawstwo uczyniło już bardzo wiele dla zbadania specyfiki narodowej literatury białoruskiej: „Як бачым, беларускім літаратуразнаўствам дастаткова шмат зроблена ў асэнсаванні нацыянальнай спецыфікі беларускай літаратуры. Вывучана яе тыпалогія, акрэслены яе характэрныя рысы, найперш арганічнае спалучэнне лірычнага, пачуццёвага і быццёвага (якое адначасова выступае як Быційнае) (s. 30). Dostrzega też liczne problemy, które dotychczas nie stanowiły przedmiotu pogłębionych studiów historycznoliterackich.

Rozdział II - Konceptualizacja problematyki narodowościowej w krytyce i publicystyce pierwszego trzydziestolecia XX wieku (Канщэптуалізащьля нацыянальнага ў крытыцы і публіщыстыцы пермай трэиі XX стагоддзя) - stanowi w gruncie rzeczy kontynuację zagadnień poruszonych w poprzednim rozdziale. Na podstawie gruntownej analizy najbardziej znaczących tekstów krytycznych i publicystycznych pierwszego trzydziestolecia XX wieku, m.in. A. Łuckiewicza (Наш культурны рост), М. Bahdanowicza (На белорусские темы, Белорусское возрождение, За сто лет, Кароткая гісторыя беларускай пісьменнасиі да XVI сталеция), Z. Biaduli (Купальская ноч, Святло, Чакайце сваіх), U. Samojły (Гэтым пераможиам: нарысы крытычнага

\footnotetext{
${ }^{2}$ Р. БАРт, Избранные работы: Семиотика. Поэтика, пер. $з$ франц. Г.К. Косикова, Москва 1994.
} 
аптымізму), J. Losika (Родная мова і яе значэнне), A. Cwikiewicza (Аб аргументах ад роздуму $i$ аб аргументах ад сэрия) Autorka dochodzi do wniosku, że zawarte $\mathrm{w}$ nich idee narodowe i tożsamościowe miały fundamentalne znaczenie $\mathrm{w}$ procesie kształtowania się jednostki świadomej swojej tradycji, języka, kultury, historii: „Дзеячы нацыянальна-адраджэнскага руху на першае месца паставілі пытанне пра станаўленне беларуса як суб'екта гісторыі, далучэнне народа да вопыту нацыянальнай гісторыі, абуджэння гістарычнай памяці” (s. 65).

Autorka bada je także z perspektywy kolonialnej, która na tym etapie rozwoju literatury białoruskiej jest przecież silnie obecna, a która uwidacznia się w częstym wykorzystywaniu toposu ojczyzny (i to nie tylko ojczyzny małej, rodzinno-domowej, ale i dużej, może nie tyle państwowej, ile narodowej), ukazywaniu Białorusi jako kraju „pomiędzy” Wschodem i Zachodem (doskonałą literacką realizację tego motywu odnajdujemy w dramacie Tutejsi (Тутэйшыля) Janka Kupały, do którego białoruscy publicyści tak często nawiązywali), czy wreszcie w samym motywie granicy (kulturowej, narodowej, państwowej).

W rozdziale III - Artystyczny model bytu narodowego w prozie biatoruskiej pierwszego trzydziestolecia XX wiekи (Мастаџкая мадэль наџьянальнага быиия у беларускай прозе першай трэиі ХХ стагоддзя) - Mielnikowa kieruje swoją uwagę na aspekt mitopoetyckości, który w rzeczywistości warunkuje czy określa narodowość. Sama koncepcja mitu i jego rozumienie jest zgodne z koncepcją R. Barthesa, sformułowaną w słynnej Mitologii. Autorka zaznacza bardzo wyraźnie, że na formowanie się białoruskiej mitologii narodowej znaczący wpływ miały ukazujące się na początku XX wieku publikacje - Labirynty (Лабірынты) і Krótka historia Białorusi (Кароткая гісторыя Беларусі) Wacława Łastouskiego, teksty prozatorskie Maksima Hareckiego (m.in. Liryczne śpiewy (Лірныя спевы)), poemat Nowa zіетіа (Новая зямля) i trylogia Na rozstajach (На ростанях) Jakuba Kołasa (wł. Kanstancina Mickiewicza), dramat Tutejsi Janka Kupały, powieść Ścieżki-dróżki (Cuежкi-дарожкі) Maksima Zareckiego czy proza Kuźmy Czornego (zwłaszcza Пошукі будучыні і Млечны шлях). Wiele miejsca w tej części monografii Mielnikawa poświęciła także kategorii Innego ${ }^{3}$. Umiejętność rozpoznania tożsamości Innego - zdaniem Badaczki - sprzyja kształtowaniu się i utwierdzaniu własnej tożsamości, otwiera człowieka nie tylko na inną kulturę, ale też na nowy system wartości oraz duchową wspólnotę ich przeżywania:

\footnotetext{
${ }^{3}$ Analizy te sytuuje w kontekście historiozoficznych i antropologicznych rozważań najbardziej znanych filozofów dialogu - Martina Bubera i Emmanuela Levinasa.
} 
„Прадстаўнікі асобнай нацыі ўспрымаюць розныя праявы «іншага» скрозь прызму ўласнай культуры, традыцый і каштоўнасцей. Такім чынам, этнічны стэрэатып «іншага» пэуным чынам уплывае на фарміраванне менталнасці рэцыпіента, выступае своеасаблівым каталізатарам ідэнтычнасці" (s. 88).

Rozdział IV - Światopoglad narodowy w świetle literatury (Нацыянальны светапогляд праз прызму літаратуры) - poświęcony został problematyce aksjologicznej i filozoficznej, uobecniającej się na płaszczyźnie białoruskiej twórczości literackiej badanego okresu. Autorkę interesuje przede wszystkim to, w jaki sposób, za pomocą jakich narzędzi i w jakim zakresie białoruska literatura ukazuje egzystencjalne dylematy człowieka, świat wartości humanistycznych, złożoność psychologicznej, osobowościowej struktury jednostki i jej mentalność. W polu zainteresowań Mielnikawej pozostaje także wpływ wierzeń pogańskich na człowieka oraz archetyp domu rodzinnego, o którym pisze: „У сістэме беларускай нацыясофіi «родны кут» як знакавая этнічная і філасофская рэальнасць беларускага быцця паўстае істотным сэнсавым элементам, праз які раскрываюцца і нацыянальныя этычныя каштоўнасці" (s. 113).

Rozdział V - Artystyczna historiozofia literatury biatoruskiej (Мастаџฺкая гістарыясофія беларускай літаратуры) - został poświęcony relacjom człowiek-historia. Na podstawie wybranych tekstów Maksima Hareckiego (m.in. Za co? (3а што?), Dwie dusze (Дзве душы), Komarowska kronika (Камароўская хроніка), Żartobliwy Pisarewicz (Жартаўлівы Пісарэвіч), Czerwone róże (Чырвоныя ружы)) і Kuźmy Czornego (powieści Ziemia (Зямля), Poszukiwania przyszłości (Пошукі будучьні), Droga Mleczna (Млечны шляx), Wielki dzień (Вялікі дзень)) Autorka podejmuje refleksję nad złożonością historycznego losu Białorusinów, zwracając szczególną uwagę na dramatyzm czasu i niestabilność sytuacji politycznej, społecznej i kulturowej lat 20. i 30. XX wieku: „Наша літаратура здолела адлюстраваць «праўду часу», драматызм жыцця ў новых абставінах, трагедыю сялянства, паказаць працэс нараджэння «новых людзей», непераборлівых ў маральных адносінах, дэфармацыю маралі" (182). Wiele miejsca poświęca także formowaniu się tzw. nowego człowieka rzuconego w wir nieustannych przemian, poszukującego własnego systemu wartości, nieustannie, nierzadko po omacku i swojego miejsca w nowej radzieckiej rzeczywistości.

Niezwykle interesująco przedstawia się ostatni, VI rozdział monografii Koncepcja jednostki w literaturze białoruskiej (Канщэпџыя асобы у беларускай літаратуры), w którym Mielnikawa zastanawia się nad sposobami kreacji postaci literackiej w twórczości białoruskich pisarzy, a także nad 
zawartymi w analizowanych tekstach refleksjami natury ontologicznej: „У творчасці беларускіх празаікаў адлюстраваны гуманістычныя ідэі першых дзесяцігоддзяў XX стагоддзя: статус і значэнне чалавека, яго роля ў свеце, пошукі глыбінных асноў чалавека" (s. 191). Autorkę interesuje nie tylko to, co jednostkowe, indywidualne $\mathrm{w}$ sylwetkach psychologicznych bohaterów badanych tekstów, ale też to, co uniwersalne, wspólne: zamysł nad sensem świata, próba odpowiedzi na pytanie o cel istnienia, o miejsce człowieka w Boskim planie świata. Nie brakuje tu także odwołań do filozofii egzystencjalnej, tak przecież silnie obecnej w literaturze białoruskiej początku XX wieku, pogłębionej refleksji nad warunkami kształtowania się podmiotowości, ukierunkowania na prezentację postaw humanistycznych i moralnych.

W swojej pracy Andżela Mielinikawa wykorzystała bogatą literaturę źródłową i przedmiotową (łącznie 250 pozycji bibliograficznych). Obok najbardziej znaczących prac historycznoliterackich, socjologicznych, filozoficznych i kulturologicznych białoruskich badaczy (m.in. A. Adamowicz, I. Babkou, P. Wasiuczenka, I. Żuk, M. Muszynski, M. Tyczyna), odnajdujemy tu także publikacje naukowców polskich (K. Michalski, F. Ziejka, R. Radzik), niemieckich (H.-G. Gadamer, G.-B. Kohler), ukraińskich (S. Andrusiw, H. Bhabha, W. Budnyj, M. Żulinskij, P. Iwanyszyn) i rosyjskich (M. Bachtin, W. Toporow, M. Bierdiajew, J. Łotman, Ł. Arutiunow, A. Bajburin, W. Chaliziew). Skonfrontowanie ze sobą różnych perspektyw, sięgnięcie do odmiennych metodologii i teorii związanych z badanym zagadnieniem pozwoliło Autorce na jego wieloaspektowy ogląd, głębsze zrozumienie procesów związanych z formowaniem się białoruskiej myśli narodowej i ich interpretację.

Szczegółowa lektura recenzowanej monografii może męczyć wielością kontekstów, nadmierną częstotliwością odwoływania się do cytatów zbyt słabo osadzonych w dyskursie własnym. Jest to jednakże lektura niezwykle skondensowana, poruszająca fundamentalne problemy białoruskiej społeczności; lektura, która zmusza nas jednocześnie do sięgnięcia po teksty źródłowe, zweryfikowania za ich pomocą utartych sądów i przekonań - i w tym zawiera się jej wartość. 